\title{
Integrating the Pasuruan Bromo-Tengger-Semeru Area Through Sustainable Tourism: A Note in Manifesting Local Economic Resilient
}

\author{
M. Khusaini ${ }^{1}$ Atu Bagus Wiguna ${ }^{2, *}$ Firdaus Finuliyah $^{3}$ \\ ${ }^{1,2,3}$ Brawijaya University, Indonesia \\ "Corresponding author. Email: $\underline{\text { atu@ub.ac,id }}$
}

\begin{abstract}
The covid-19 pandemic hits the tourism sector by limiting economic mobility, making local business suffer. The case is also genuine in The Pasuruan Bromo - Tengger Semeru Area Indonesia, however as the Prioritized Tourism Destination, it also holds an opportunity to manifest business resilience by integrating the locals with thematic tourism. Therefore, this research has two objectives: 1) Identify the opportunity for implementing sustainable tourism concept; and 2) Create a Sustainable Tourism model for The Pasuruan Bromo - Tengger - Semeru. Through group discussion with government representatives, local businesses, and communities, we found that 2 districts (Tosari and Tutur) appear to be agro-tourism and culture-based tourism leaders. Even Though it is attractive, unfair competition among tourism businesses still clouds collaboration due to high individualism among local tourism businesses. In light of this situation, we suggest Pasuruan Tourism Board as a legal entity to enable professional management that led to greater local participation of tourism actors. As local tourism is based on community initiative, this research may be used as the development consideration to build the family business in The Pasuruan Bromo - Tengger - Semeru to improve social welfare as the local economic resilient manifestation.
\end{abstract}

Keywords: Sustainable Tourism, Bromo-Tengger-Semeru, Local Business.

\section{INTRODUCTION}

Bromo Tengger Semeru or (BTS) is one of Indonesia's Strategic National Tourism Areas [1]. It resonates with Presidential Regulation No. 3 of 2016 and Presidential Regulation No. 80 of 2019 that suggest BTS as the strategic project for accelerating tourist visits and investment in Indonesia. Surrounded by four Indonesian regencies (Pasuruan Regency, Probolinggo Regency, Lumajang Regency, and Malang Regency) the BTS has become a growth pole for many aspects of the four regencies, including social, economic, and cultural development. In this case, Pasuruan Regency, through Pasuruan Regency Regulation Number 6 of 2016, already has an institutional commitment to developing local characteristic-based tourism.

Due to the growing concern of locality, sustainable tourism is a significant concern as the basic line for the local development planning in Pasuruan Regency. Consequently, tourism would grow not only to create economic value but also to preserve nature and respect the needs of residents $[2,3]$. The implication of this approach is the creation of a unique interaction between the government, society, and tourism businesses that require the governance of tourism institutions that can facilitate all these interests fairly [4].

As tourism continues to grow, unfortunately, there was a COVID-19 that put considerable pressure in many sectors including tourism business that is related with BTS. Globally, this pandemic causes a declining number of visitors, so it impacts travel agencies to hotels by more than $90 \%$ [5]. At this point, tourism businesses experience economic shock that would challenge their resiliency toward managing uncertainty [6]. Although international tourism might have entered the era of a 'new normal', tourism businesses have to reconsider their business models in line with new governmental requirements and consumer expectations which still unclear in the future [7].

Implementing sustainable tourism through the local business is beneficial for many tourism actors, yet, this responsibility is challenged not only by 
uncertainty caused by the pandemic but also by unsolved obstacles in manifesting the local economy resilient in Pasuruan regency. Previously, it was found that the source of problems in Business Development in BTS are the lack of qualified tourism management, pessimistic mindset of the locals, and poor-quality infrastructure [8]. Furthermore, unhealthy competition among communities in the tourism sector also stagnates the tourism business. Therefore, this research aims: 1) Identify the opportunity for implementing sustainable tourism concept; and 2) Create Sustainable Tourism model for The Pasuruan Bromo - Tengger - Semeru.

\section{LITERATURE REVIEW}

\subsection{Scope of Tourism Development in Pasuruan}

Based on Act No. 9 of 2010, tourism is defined as a variety of tourism activities supported by various facilities and services provided by the community, entrepreneurs, government and local government. According to Government Regulation of the Republic of Indonesia no. 50 of 2011 concern in the National Tourism Development Master Plan 2010 - 2025 is a whole activity related to tourism. It is multidimensional and multidisciplinary that emerges as a form of needs of every person and country and interaction between tourists and local communities, local governments, entrepreneurs, and others.

The tourism development component consists of 4 attributes or called 4A: attractions, accessibility, amenities, and ancillary services [9]. Firstly, attractions are the starting point of becoming a tourist spot because it could motivate tourists to visit the destination. Secondly, amenities are a variety of facilities and services that tourists need at their destination, such as accommodation, food, entertainment, and other facilities. Thirdly, accessibility refers to the availability of transportation and connecting facilities to tourist destinations. Finally, ancillary services are all facilities and services for creating a sustainable tourism industry, such as institutional sustainability, availability of management organizations, information and marketing systems, and reliable security systems.

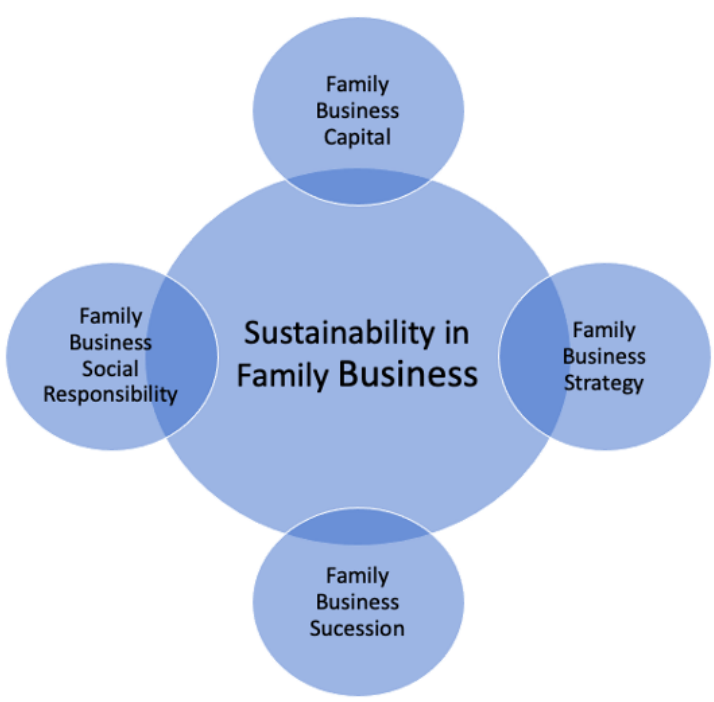

Figure 1. Sustainability in Family Business

In addition, local tourism characteristics are depicted by a sustainable family business that incorporates small tourism and hospitality businesses. Four clusters covering the main issues on sustainable family business are capital, strategy, succession, and social responsibility (see fig.1) [10]. Family capital is defined as the family's human, social, and financial capital as the business input factors. Then, the strategy of individuals toward business would be crucial to maintain their success i.e. company's assets management, the age of the company, personnel management, the weekly hours of the owner in the company, and family employees management. Family businesses are also involved in the community, resulting in the business size. Lastly, business succession covers long business engagement with local communities that include future business models and family control.

\subsection{Theoretical Perspective on Sustainable Tourism and Business Resilient}

In General, tourism sectors have four main elements, namely a) demand; b) supply; c) markets and institutions; and d) the regulator who moves the three elements [11]. Based on figure 2 about the tourism system, the government policies for tourism can affect the demand and supply of tourism, which can control the product or tourism object. 


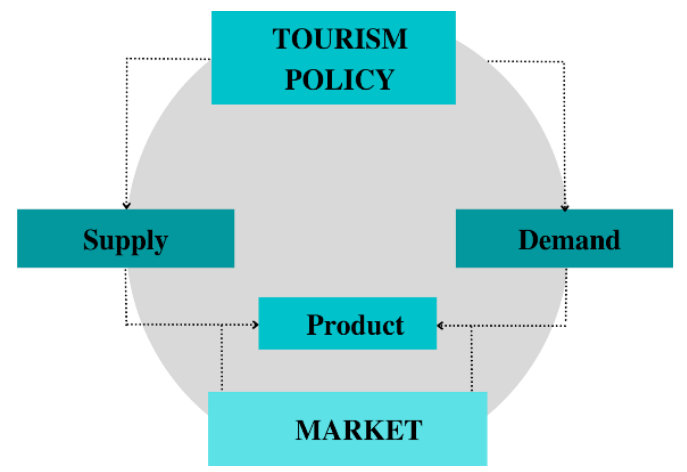

Figure 2. Tourism System

In terms of supply, the development and marketing of tourism objects to the market and tourism actors, and in terms of demand to buy and use goods and services offered by the tourism object. Therefore, demand in tourism consists of various elements that differ in nature and form and benefits and uses for tourists. Products produced by tourism industry companies and the demand in tourism is not only limited during the period of travel, but also the most crucial element of demand is at the time before the trip is held such as, availability of information, travel documents, tickets, hotel reservations, money changers, and other needs. Further, in this system, tourists determine the price balance, which means tourism is a prestige good different from supplydemand for normal goods [12].

A well-managed tourism system benefits the involved actors; however, each tourism actor's readiness plays a vital role in determining the magnitude of the benefit. The Tourism Area Life Cycle (TALC) concept states that the development of a tourism area has S-Shaped characteristics, where the vertical axis represents the number of tourists and the horizontal axis represents time [13]. Tourism is growing with the participation of local communities who provide attractions and tourism infrastructure, but as the involvement of local communities decreases, a drop of tourism visitors will be in order.

\section{METHOD}

This research is carried out in the Pasuruan Regency, especially in the Bromo-Tengger-Semeru area. In answering the research questions, the data was collected by conducting three step serial group discussion where the participants were selected purposely. In the first place, discussion was conducted with the government of Pasuruan Regency (the board of planning agency and government tourism office) to determine the priority of tourism development. As a result, six districts were selected prior to their distance with BTS and the readiness of the tourism management board. Further, two districts (Tutur and Tosari) became the main focus of this research as they posed competitiveness in terms of location and the existence of local tourism management.

Subsequently, two group discussions were conducted in those two districts where the management board of tourism destinations, local communities and small-medium enterprises were invited to participate. During the discussion, participants were interviewed and asked to give their opinions on strategies for developing sustainable tourism business in the BTS area. The discussions were held based on a semi-structured interview protocol where the questions cover 1) identifying the SWOT factors of the tourism sector of BTS and (b) how these factors can be helpful in formulating future strategies for developing sustainable tourism business in Pasuruan [14].

Afterward, the data were analyzed by StrengthWeakness-Opportunity-Threat (SWOT) and Quantitative Strategic Planning Matrix (QSPM) [15]. Some participants, i.e., the government of Pasuruan Regency and academicians, are further contacted to evaluate the findings and assign weights and attractive scores for each SWOT factor [14]. Finally, this study offers a prospective strategy to manifest sustainable tourism where the district of Tutur and Tosari took place as the role model for local tourism business development.

\section{DISCUSSION}

\subsection{Mapping the Potential of BTS Tourism System}

Based on our research through group discussion with government representatives, local business and communities, we found that two districts (Tosari and Tutur) appear to be the leaders for integrating agrotourism and culture-based tourism to support BTS as the main tourism destination. SWOT and QSPM analysis are used to explain development plans for the supporting tourism sectors from the potentials and problems.

\subsubsection{Tutur Tourism Development}

Tutur is one of the districts in Pasuruan, characterized by many agricultural areas which have been managed as tourism destinations. SWOT and QSPM analysis then used to identify, evaluate, and 
offer the prospective strategies. The Tutur's area can be seen in Figure 3 and Table 1 present the SWOT analysis of Tutur.

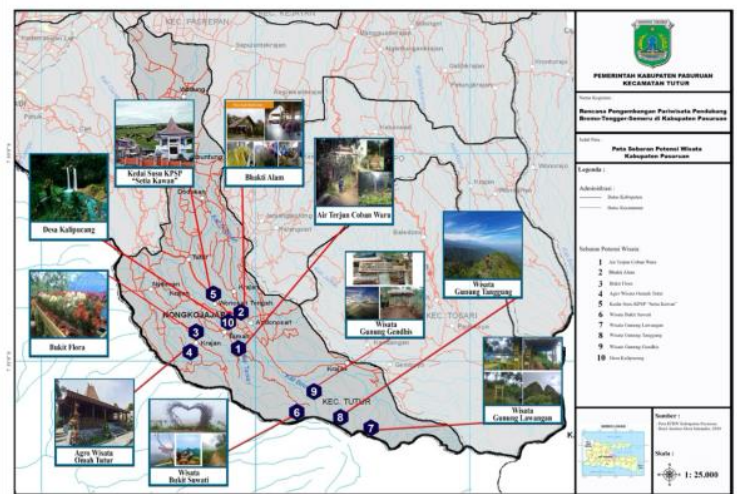

Figure 3. Tutur's Area

Figure 3 shows agritourism attractions in the district of Tutur that include: fruit-harvesting and flora-based tourism (Durian, apple, Krisan and Paprika); culinary-based tourism (Bukit Flora, Oemah Tutur, Susu "KPSP" Setia Kawan), hiking tourism (Bukit Suwati, Mount Lawangan, Mount Gendhis) and village tourism (Kalipucang Village). From many objects that can be visited, we can analyze the SWOT to develop sustainable tourism.

Table 1. Tutur's SWOT Analysis

\section{Strength}

1. Most of the agritourism destination has their tourism management board and ease of accessibility

2. There is a tourism village which is managed very well

3. There are abundant in agricultural products

4. There are mountain-based tourism as specialized tourism theme

5. There is Government Regulation no.6 of 2016 as the guidelines to develop sustainable tourism

Weakness

1. Some destinations have not been managed professionally

2. Lack of marketing and promotion

3. Limited integrated tourism with other destinations

4. Limited fund to develop facilities and infrastructure

Opportunities

1. The existence of Presidential Regulation no. 80 of 2019 to develop agro-tourism in Pasuruan Regency

2. Many additional services that could be offered to the tourist

3. There is a Small Medium Enterprise community in Pasuruan regency which could be elaborated in marketing and promotion

4. The availability of national economic recovery stimulus program that focuses on local business

Threats

1. Lack of Infrastructures and amenities in several destinations

2. Competitive tourism business from others area beside Pasuruan Regency

Table 1 explains SWOT analysis in the district of Tutur. In general, the strength of the tourism area is the ease of accessibility. Also, most of the agritourism destinations have a management board that is actively doing daily tourism business. However, the management process still lacks marketing and promotion. In addition, although the tourism product has almost similar characteristics, the individualistic behavior limited any favor to make an integrated tourism package. Inability to access sources of business funding makes tourism grow slower than expected. External and internal factors analysed as follows.

Table 2. External Factor Estimation Matrix (EFEM) in Tutur

\begin{tabular}{|c|c|c|c|c|}
\hline No & External Factors & (A) & (B) & $(\mathrm{A} \times \mathrm{B})$ \\
\hline & Strength: & & & \\
\hline 1 & $\begin{array}{l}\text { The existence of } \\
\text { Presidential } \\
\text { Regulation no. } 80 \text { of } \\
2019 \text { to develop agro- } \\
\text { tourism in pasuruan } \\
\text { Regency }\end{array}$ & 0,2 & 4 & 0,8 \\
\hline 2 & $\begin{array}{l}\text { Many additional } \\
\text { services that could be } \\
\text { offered to the tourist }\end{array}$ & 0,1 & 3 & 0,3 \\
\hline 3 & $\begin{array}{l}\text { There is a Small } \\
\text { Medium Enterprise } \\
\text { community in } \\
\text { Pasuruan regency } \\
\text { which could be } \\
\text { elaborated in } \\
\text { marketing and } \\
\text { promotion }\end{array}$ & 0,2 & 3 & 0,6 \\
\hline 4 & $\begin{array}{l}\text { The availability of a } \\
\text { national economic } \\
\text { recovery stimulus } \\
\text { program }\end{array}$ & 0,3 & 4 & 1,2 \\
\hline & Sub-Total & & & 2,9 \\
\hline
\end{tabular}




\begin{tabular}{|l|l|c|c|c|}
\hline & Weakness: & & & \\
\hline 1 & $\begin{array}{l}\text { Lack of Infrastructures } \\
\text { and amenities in } \\
\text { several destinations }\end{array}$ & 0,1 & 2 & 0,2 \\
\hline 2 & $\begin{array}{l}\text { Competitive tourism } \\
\text { business from others } \\
\text { area beside Pasuruan } \\
\text { Regency }\end{array}$ & 0,1 & 3 & 0,3 \\
\hline & Sub-Total & & & 0,5 \\
\hline & Total & & & 2,4 \\
\hline
\end{tabular}

Table 3. Internal Factor Estimation Matrix (IFEM) in Tutur

\begin{tabular}{|c|c|c|c|c|}
\hline No & Internal Factors & (A) & (B) & $(\mathrm{A} \times \mathrm{B})$ \\
\hline & Strength: & & & \\
\hline 1 & $\begin{array}{l}\text { Most of agritourism } \\
\text { destination has their } \\
\text { tourism management } \\
\text { board and ease of } \\
\text { accessibility }\end{array}$ & 0,3 & 4 & 1,2 \\
\hline 2 & $\begin{array}{l}\text { There is tourism } \\
\text { village which is } \\
\text { managed very well }\end{array}$ & 0,25 & 4 & 1 \\
\hline 3 & $\begin{array}{l}\text { There are abundant in } \\
\text { agricultural products }\end{array}$ & 0,5 & 4 & 2 \\
\hline 4 & $\begin{array}{l}\text { There are mountain- } \\
\text { based tourism as } \\
\text { specialize tourism } \\
\text { theme }\end{array}$ & 0,05 & 3 & 0,15 \\
\hline 5 & $\begin{array}{l}\text { There is Government } \\
\text { Regulation no. } 6 \text { of } \\
2016 \text { as the guidelines } \\
\text { to develop sustainable } \\
\text { tourism }\end{array}$ & 0,05 & 4 & 0,2 \\
\hline & Sub-Total & 0,7 & & 4,35 \\
\hline & Weakness: & & & \\
\hline 1 & $\begin{array}{l}\text { Some destinations } \\
\text { have not been } \\
\text { managed } \\
\text { professionally }\end{array}$ & 0,05 & 2 & 0,1 \\
\hline
\end{tabular}

\begin{tabular}{|l|l|c|c|c|}
\hline 2 & $\begin{array}{l}\text { Lack of marketing and } \\
\text { promotion }\end{array}$ & 0,1 & 3 & 0,3 \\
\hline 3 & $\begin{array}{l}\text { Limited integrated } \\
\text { tourism with other } \\
\text { destinations }\end{array}$ & 0,05 & 3 & 0,15 \\
\hline 4 & $\begin{array}{l}\text { Limited fund to } \\
\text { develop facilities and } \\
\text { infrastructure }\end{array}$ & 0,1 & 4 & 0,4 \\
\hline & Sub-Total & 0,3 & & 0,95 \\
\hline & Total & & & 3,4 \\
\hline
\end{tabular}

Depicted on the internal and external factors, IFE and EFE score are 3,4 and 2,4, accordingly. Hence, the strategy of growth and build is needed by doing Intensive Strategy (such as market penetration, market development, and product development) or integrative strategy (such as backward integration, forward integration, and horizontal integration). The list of strategies are shown in table 4.

Table 4. SWOT Strategies for Sustainable Tourism Business in Tutur

\section{SO Strategies}

1. Designing agro-tourism package with centered in the Tutur and supported by other destinations

2. Designing additional tourist attractions

3. Cooperating between tourist destination and the Small Medium Enterprise community

4. Cooperating with tour guide and porter especially in mountain tourism destination

\section{ST Strategies}

1. Empowering the community to offers tourism facilities such as transportation and accommodation services

2. Local advantages as the main branding

WO Strategies

1. Designing an business plan especially and organizational structure of tourism management for each destination

2. Doing centralized promotion and marketing in Pasuruan regency about agritourism

3. Prioritizing to develop tourism facilities and infrastructure in tourism destinations

\section{WT Strategies}

1. Optimizing the tourism management of each destinations and the role of tourism community (Kelompok Sadar Wisata - POKDARWIS) 
2. Educating the community about the importance of the community participant in tourism

From internal and external factors, several development strategies appear and are ranked by QSPM analysis to rank the strategies according to the total attractive score in EFEM and IFIM.

Table 5. Final QSPM analysis for The District of Tutur

\begin{tabular}{|c|c|c|c|}
\hline Rank & Strategy & Input & score \\
\hline 1 & $\begin{array}{l}\text { Designing additional } \\
\text { tourist attractions }\end{array}$ & $\mathrm{S}-\mathrm{O}$ & 8,45 \\
\hline 2 & $\begin{array}{l}\text { Designing agro-tourism } \\
\text { package with centered in } \\
\text { the Tutur and supported by } \\
\text { other destinations }\end{array}$ & $\mathrm{S}-\mathrm{O}$ & 8,2 \\
\hline 3 & $\begin{array}{l}\text { Educating the community } \\
\text { about the importance of the } \\
\text { community participant in } \\
\text { tourism }\end{array}$ & W-T & 8,05 \\
\hline 4 & $\begin{array}{l}\text { Local advantages as the } \\
\text { main branding }\end{array}$ & S-T & 7,95 \\
\hline 5 & $\begin{array}{l}\text { Cooperating between } \\
\text { tourist destination and the } \\
\text { Small Medium Enterprise } \\
\text { community }\end{array}$ & $\mathrm{S}-\mathrm{O}$ & 7,8 \\
\hline 6 & $\begin{array}{l}\text { Optimizing the tourism } \\
\text { management of each } \\
\text { destinations and the role of } \\
\text { tourism community } \\
\text { (Kelompok Sadar Wisata - } \\
\text { POKDARWIS) }\end{array}$ & W-T & 7,5 \\
\hline 7 & $\begin{array}{l}\text { Empowering the } \\
\text { community to offers } \\
\text { tourism facilities such as } \\
\text { transportation and } \\
\text { accommodation services }\end{array}$ & S-T & 7,45 \\
\hline 8 & $\begin{array}{l}\text { Doing centralized } \\
\text { promotion and marketing } \\
\text { in Pasuruan regency about } \\
\text { agritourism }\end{array}$ & $\mathrm{W}-\mathrm{O}$ & 6,9 \\
\hline 9 & $\begin{array}{l}\text { Designing an business plan } \\
\text { especially and } \\
\text { organizational structure of }\end{array}$ & $\mathrm{W}-\mathrm{O}$ & 6,4 \\
\hline
\end{tabular}

\begin{tabular}{|c|c|c|c|}
\hline & $\begin{array}{l}\text { tourism management for } \\
\text { each destination }\end{array}$ & & \\
\hline 10 & $\begin{array}{l}\text { Cooperating between } \\
\text { tourist destination and the } \\
\text { Small Medium Enterprise } \\
\text { community }\end{array}$ & $\mathrm{S}-\mathrm{O}$ & 6,05 \\
\hline 11 & $\begin{array}{l}\text { Prioritizing to develop } \\
\text { tourism facilities and } \\
\text { infrastructure in tourism } \\
\text { destinations }\end{array}$ & $\mathrm{W}-\mathrm{O}$ & 6 \\
\hline
\end{tabular}

\subsubsection{Tosari Tourism Development}

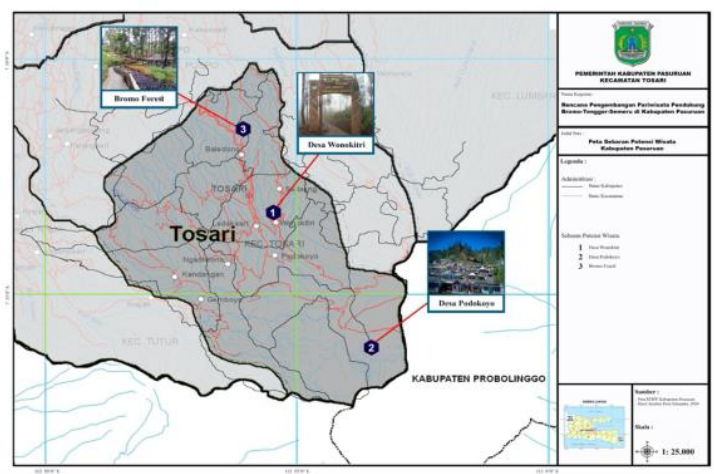

Figure 4. Tosari's Area

Tosari is one of the tourism areas near BTS that is characterized by local culture, namely Tengger. There are several tourism attractions including: natural scenery tourism (Bromo Fun Tracking and Bromo Forest), plantation-based tourism (edelweiss and horticulture production), Tengger culture-based tourism (Podokoyo and Wonokitri Village) which regularly shows local ceremonies, such as Karo, Kasodo, Entas-Entas, Barikan, liwet, and the art of Batik Tengger. Alongside the strength of their culture, yet, none of the tourists are offered by any integrated cultural based tourism package. The mapping SWOT analysis of the district of Tosari is shown in table 6 .

Table 6. SWOT Analysis in Tosari

Strength

1. There are a well-developed tourism village

2. There is an attraction with the unique culture, namely Tengger

3. There are abundant agricultural products

4. There is creative economy based on local culture

5. There is a regulation No. 6 of 2016 as a guideline for tourism 
Weakness

1. Lack of marketing and promotion

2. Limited integrated tourism with other destinations

Opportunity

1. There is a presidential regulation no. 80 of 2019 as the strategic project for accelerating tourism sectors

2. There are some tourism villages which is recognized by Pasuruan Regency

3. There is a Small Medium Enterprise community in Pasuruan regency

4. There is the national economic recovery stimulus program that focuses on local business

Threats

1. There is a social conflict among local businesses

2. Limited accessibility in some destinations

3. There is a bad perception on tourism security

4. There are competitive tourism destination Beside Pasuruan Regency (Malang, Batu, Probolinggo)

The SWOT analysis, then, put in external and internal factors matrix as shown in table 7 .

Table 7. External Factor Estimation Matrix (EFEM)

\begin{tabular}{|c|c|c|c|c|}
\hline No & External factors & (A) & (B) & $(\mathrm{A} \times \mathrm{B})$ \\
\hline & Strength: & & & \\
\hline 1 & $\begin{array}{l}\text { There is a presidential } \\
\text { regulation no. } 80 \text { of } \\
2019 \text { as the strategic } \\
\text { project for } \\
\text { accelerating tourism } \\
\text { sectors }\end{array}$ & 0,3 & 4 & 1,2 \\
\hline 2 & $\begin{array}{l}\text { There are a well- } \\
\text { developed tourism } \\
\text { village }\end{array}$ & 0,15 & 4 & 0,6 \\
\hline 3 & $\begin{array}{l}\text { There is a Small } \\
\text { Medium Enterprise } \\
\text { community in } \\
\text { Pasuruan regency }\end{array}$ & 0,1 & 3 & 0,3 \\
\hline 4 & $\begin{array}{l}\text { There is the national } \\
\text { economic recovery } \\
\text { stimulus program that } \\
\text { focuses on local } \\
\text { business }\end{array}$ & 0,2 & 4 & 0,8 \\
\hline & Sub-Total & & & 2,9 \\
\hline & Weakness: & & & \\
\hline
\end{tabular}

\begin{tabular}{|c|c|c|c|c|}
\hline 1 & $\begin{array}{l}\text { There is a social } \\
\text { conflict among local } \\
\text { businesses }\end{array}$ & 0,1 & 1 & 0,1 \\
\hline 2 & $\begin{array}{l}\text { Limited accessibility } \\
\text { in some destinations }\end{array}$ & 0,05 & 2 & 0,1 \\
\hline 3. & $\begin{array}{l}\text { There is a bad } \\
\text { perception on tourism } \\
\text { security }\end{array}$ & 0,05 & 2 & 0,1 \\
\hline 4 & $\begin{array}{l}\text { There are competitive } \\
\text { tourism destination } \\
\text { Beside Pasuruan } \\
\text { Regency (Malang, } \\
\text { Batu, Probolinggo) }\end{array}$ & 0,1 & 3 & 0,3 \\
\hline & Sub-Total & & & 0,6 \\
\hline & Total & & & 2,3 \\
\hline
\end{tabular}

Table 8. Internal Factor Estimation Matrix (IFEM) in

\begin{tabular}{|c|c|c|c|c|}
\hline \multicolumn{5}{|c|}{ Tosari } \\
\hline No & Internal Factors & (A) & (B) & $(\mathrm{A} \times \mathrm{B})$ \\
\hline & Strength: & & & \\
\hline 1 & $\begin{array}{l}\text { There are a well- } \\
\text { developed tourism } \\
\text { village }\end{array}$ & 0,25 & 4 & 1 \\
\hline 2 & $\begin{array}{l}\text { There is an attraction } \\
\text { with the unique } \\
\text { culture, namely } \\
\text { Tengger }\end{array}$ & 0,2 & 4 & 0,8 \\
\hline 3 & $\begin{array}{l}\text { There are abundant } \\
\text { agricultural products }\end{array}$ & 0,1 & 3 & 0,3 \\
\hline 4 & $\begin{array}{l}\text { There is creative } \\
\text { economy based on } \\
\text { local culture }\end{array}$ & 0,2 & 4 & 0,8 \\
\hline 5 & $\begin{array}{l}\text { There is a regulation } \\
\text { No. } 6 \text { of } 2016 \text { as a } \\
\text { guideline for tourism }\end{array}$ & 0,05 & 4 & 0,2 \\
\hline & Sub-Total & & & 3,1 \\
\hline & Weakness: & & & \\
\hline 1 & $\begin{array}{l}\text { Lack of marketing and } \\
\text { promotion }\end{array}$ & 0,1 & 3 & 0,3 \\
\hline 2 & $\begin{array}{l}\text { Limited integrated } \\
\text { tourusm with other } \\
\text { destinations }\end{array}$ & 0,1 & 3 & 0,3 \\
\hline
\end{tabular}




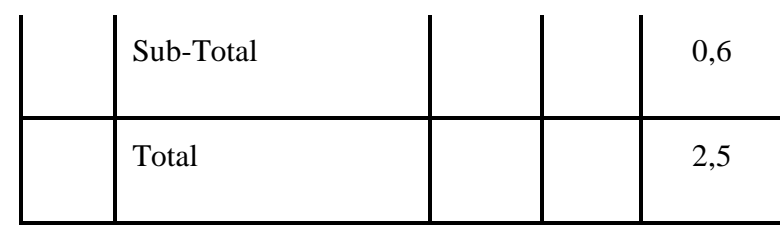

Table 8 explains the internal and external factors, where IFE score is 2,5 and EFE score is 2,3. The score indicates that the strategy of "hold and maintain" is appropriate for this district. Thus, the available strategies are arranged in table 9.

Table 9. SWOT Strategies for Sustainable Tourism Business in Tosari

\section{SO Strategies}

1. Strengthening aspects with traditional tourism attraction from local culture (Tengger)

2. Creating local cultural-based tourism package

3. Creating with routine cultural based activities (festivals) to strengthen the tourism attraction

4. Cooperating with small medium enterprise community to expand local business especially accommodation for tourist

\section{ST Strategies}

1. Increasing the engagement of local community in tourism activities

2. Providing security office which collaborate with tourism police to ensure the tourist's safety

\section{WO Strategies}

1. Doing centralized promotion and marketing in Pasuruan regency about cultural based tourism

2. Develop new business to support accommodation and other facilities that is related to cultural based tourism

\section{WT Strategies}

1. Educate tourism management in each destination about the importance of technology in marketing and promotion which could increase information delivery and minimize social conflict

2. Prioritizing to develop infrastructure in destination tourism

Afterward, internal and external factors can get several strategic priorities for tourism development in the district of Tosari., Using QSPM analysis, the strategies are ranked regarding to the total attractive score in EFEM and IFIM in table 10.
Table 10. Final QSPM analysis for suggested SWOT strategies in Tosari

\begin{tabular}{|c|c|c|c|}
\hline Rank & Strategy & Input & Score \\
\hline 1 & $\begin{array}{l}\text { Creating with routine } \\
\text { cultural based activities } \\
\text { (festivals) to strengthen } \\
\text { the tourism attraction }\end{array}$ & $\mathrm{S}-\mathrm{O}$ & 7 \\
\hline 2 & $\begin{array}{l}\text { Creating local cultural- } \\
\text { based tourism package }\end{array}$ & $\mathrm{S}-\mathrm{O}$ & 6,95 \\
\hline 3 & $\begin{array}{l}\text { Educate tourism } \\
\text { management in each } \\
\text { destinations about the } \\
\text { importance of } \\
\text { technology in marketing } \\
\text { and promotion which } \\
\text { could increase } \\
\text { information delivery } \\
\text { and minimize social } \\
\text { conflict }\end{array}$ & W-T & 6,75 \\
\hline 4 & $\begin{array}{l}\text { Strengthening aspects } \\
\text { with traditional tourist } \\
\text { attraction from local } \\
\text { culture (Tengger) }\end{array}$ & $\mathrm{S}-\mathrm{O}$ & 6,7 \\
\hline 5 & $\begin{array}{l}\text { Doing centralized } \\
\text { promotion and } \\
\text { marketing in Pasuruan } \\
\text { regency about cultural } \\
\text { based tourism }\end{array}$ & W-O & 6,4 \\
\hline 6 & $\begin{array}{l}\text { Develop new business to } \\
\text { support accommodation } \\
\text { and other facilities that } \\
\text { is related to cultural } \\
\text { based tourism }\end{array}$ & $\mathrm{W}-\mathrm{O}$ & 6,3 \\
\hline 7 & $\begin{array}{l}\text { Cooperating with small } \\
\text { medium enterprise } \\
\text { community to expand } \\
\text { local business especially } \\
\text { accommodation for } \\
\text { tourist }\end{array}$ & $\mathrm{S}-\mathrm{O}$ & 6,25 \\
\hline 8 & $\begin{array}{l}\text { Increasing the } \\
\text { engagement of local } \\
\text { community in tourism } \\
\text { activities }\end{array}$ & S-T & 6,2 \\
\hline
\end{tabular}




\begin{tabular}{|l|l|l|l|}
9 & $\begin{array}{l}\text { Prioritizing to develop } \\
\text { infrastructure in } \\
\text { destination tourism }\end{array}$ & W-T & 5,05 \\
\hline 10 & $\begin{array}{l}\text { Providing security } \\
\text { office which collaborate } \\
\text { with tourism police to } \\
\text { ensure the tourist's } \\
\text { safety }\end{array}$ & S-T & 4,85 \\
\hline
\end{tabular}

\subsection{The Opportunity for Implementing Sustainable Tourism Concept}

Based on the Minister of Forestry No. 178 / Menhut-II / 2005 dated June 29, 2005, The main area of BTS is Bromo Tengger Semeru National Park. This area has a natural ecology of the mountains and the culture of the locals, called Tengger. This area is an attractive tourism destination with natural and unique cultural objects. From nature, attractions of Bromo Tengger Semeru National Park include the presence of rare endemic flora and an active volcanoes ecosystem. There is a local culture, namely the Tengger. There are cultural traditions that institutionalize in the community (especially the Tengger ethnic group), such as: Karo, Yadnya Kasodo, Entas-entas, Unan-unan, Pujan and Mubeng.

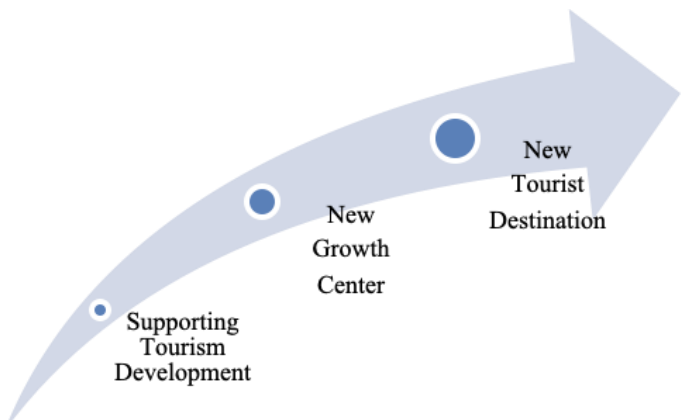

Figure 5. Direction of Tourism Development in Pasuruan Regency

Figure 5 visualizes the direction of tourism development mandated by Presidential Regulation No. 80 of 2019, BTS became one of the new growth centers for several surrounding areas, especially Pasuruan Regency. Economic activities that deserve to be a trigger for growth in the BTS Area is Tourism based on tengger culture. Besides, the agropolitan program also supports the acceleration of the BTS Development through agrotourism in the district of Tosari and Tutur. Using a development strategy centered on the new growth pole (BTS in this case), such as tourism villages and agro-tourism, it is necessary to improve the quality of facilities and infrastructure, public health, and employment opportunities that are able to employ local residents.

\subsection{Sustainable Tourism Model for The Pasuruan Bromo-Tengger-Semeru}

The Sustainable Tourism Model becomes the guideline to develop tourism business near Bromo Tengger Semeru (BTS). Basically, the concept elaborates traditional tourism management by maintaining a balance between tourist needs, resources, and long-term time horizon considerations. The direction of sustainable tourism development can be seen in figure 6 which is adopted based on Grundey [16].

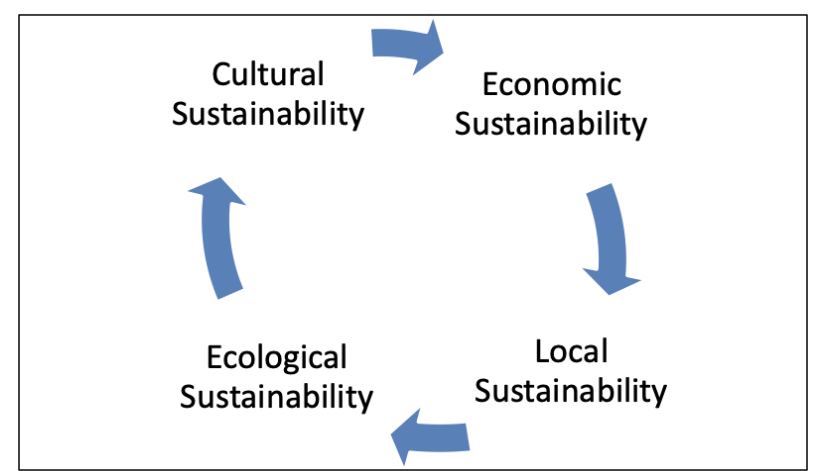

Figure 6. Principles of Tourism Development Based on the Concept of Sustainable Tourism

Based on the figure 6 , the principle of tourism development is relevant to be applied considering some regulations and local existing conditions in the tourism area. The conditions include 1) the direction of tourism development of Pasuruan Regency is the development of Sustainable Tourism through Presidential Regulation No. 80 of 2019 and Tourism Regulation no. 6 of 2016 ; 2) The commitment of the government in tourism development priority that can be a source of new growth; 3) Most tourism destinations have the advantages of natural and a beautiful environment; 4) Surrounded by ecologicalfriendly conditions; 4) Have a community that preserves local culture. Therefore, the concept development is carried out by four pillars, 1.) Economic, 2.) Environmental, 3.) Social; and 4.) Institutional. In addition, BTS Supporting tourism can be seen in figure 7 . 


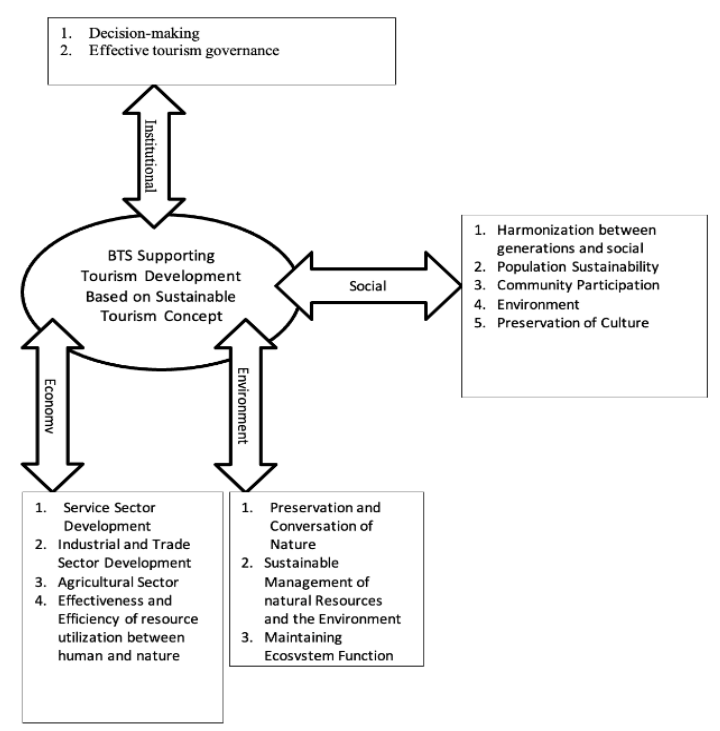

Figure 7. BTS's Local Business Tourism Development Concept

Figure 7 is adopted based on Kernel, where further development concepts are needed to implement sustainable tourism management [17]. The figure incorporates four pillars: social, economic, environment, and institution. After that, considering all the pillars, the integration of business tourism becomes very important to be designed. The concept integration of tourism management can be seen in figure 8 .

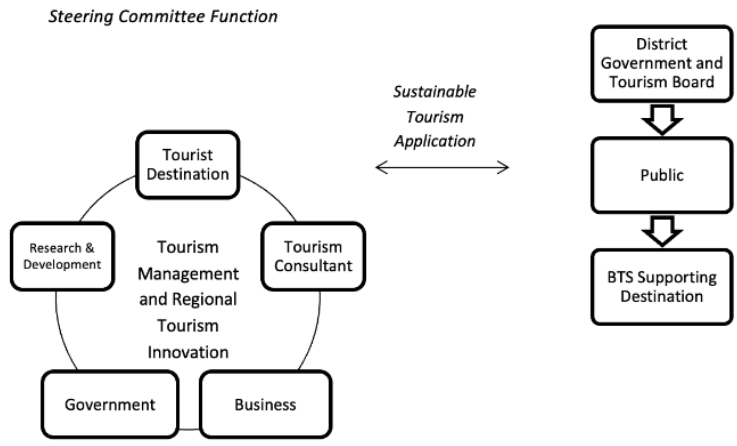

Figure 8. Integrated Tourism Management Concept supporting BTS Pasuruan Regency

Figure 8 is adopted based on Grundey about integrated tourism management concept [16]. The purpose of this concept is to integrate the implementation of sustainable tourism by elaborating various stakeholders from the level of tourism destination managers to the government level as a regulator. The main component of this concept is characterized by the central role of the tourism board where it is an organization consisting of all related parties in terms of tourism business. Thus, every region and tourism destination has a measurable business development governance in attraction management, finance, marketing and promotion, inventory of tourism condition database, and tourism innovation efforts based on their potential.

In addition, there are two important groups based on the function of the tourism organization: the steering committee and the implementation function. The steering committee function carries out business development functions and creates a tourism business climate that requires consulting research, and socialization activities. On the other hand, the implementing function executes the daily tourism business in a BTS area.

\section{CONCLUSION}

The development of BTS - Local Business Tourism in Pasuruan Regency would be a new growth center for the economic development in Pasuruan Regency. As a business tourism area, the districts of Tosari and Tutur have internal advantages where agriculture and local culture become the main tourism attractions. Uncertainty caused by the pandemic makes resiliency of local tourism business become a major concern, therefore, BTS and the local tourism business should coexist by respecting economic, social, natural, and institutional pillars as a sustainable tourism concept. Centralized tourism board should be designated to cover daily management matters which could cover various business characteristics while reducing individualistic behavior among local businesses. Lastly, to address sustainability issues, further consideration should be put on family business concepts especially in tourism sectors which include the aspects of business capital, strategy, social responsibility, and the business succession.

\section{REFERENCES}

[1] S. Yacob, N. Qomariyah, J. Marzal, and A. Maulana. Strategi Pemasaran Desa Wisata, 2021. [Online] Available: WIDA Publishing.

[2] J. Liu, P. Nijkamp, X. Huang, and D. Lin. Urban livability and tourism development in China: Analysis of sustainable development by means of spatial panel data, Habitant International, Vol. 68, pp 99-107.

[3] H. Goodwin. Responsible tourism: Using tourism for sustainable development, 2nd 
edition, Oxford: Goodfellow Publications, 2016. [Online] Available: Researchgate.

[4] T. Sofield, J. Guia, and J. Specht. Organic 'folkloric' community driven place- making and tourism, Tourism Management 61, pp 1-22, 2017.

[5] S. R. P. Wulung, A. N. Latifah, A. F. Saidah, A. S. Ningtias, and F. Yasyfa. Dampak Covid-19 pada Destinasi Pariwisata Prioritas Bromo Tengger Semeru, Jurnal Ilmiah Pariwisata, vol 26, no 2, pp 123-132, 2021.

[6] G.I. Bhaskara and V. Filimonau. The COVID19 pandemic and organisational learning for disaster planning and management: A perspective of tourism businesses from a destination prone to consecutive disasters, Journal of Hospitality and Tourism Management, vol 46, pp 364-375, 2021.

[7] C. M. Hall, D. Scott, and S. Gössling. Pandemics, transformations and tourism: be careful what you wish for, Tourism Geographies, vol 22, No. 3, pp 577-598, 2020.

[8] K. M. Noviantoro. Evaluasi Potensi Wisata Bromo-Madakaripura Sebagai Ekowisata Dalam Meningkatkan Perekonomian Masyarakat Sekitar, Iqtishodiyah: Jurnal Ekonomi Dan Bisnis Islam, Vol 6, No. 1, January 2020, pp 49-62.

[9] C. F. Lee. An investigation of factors determining industrial tourism attractiveness, Tourism and Hospitality Research, Vol 0, No. 0, pp 1-14, 2015.
[10] J. J. Ferreira, C. I. Fernandes, F. Schiavone, and R. V. Mahto. Sustainability in Family BusinessA Bibliometric Study and a Research Agenda, Technological Forecasting and Social Change173, 2021.

[11] J. Damanik and H. F. Weber, Perencanaan ekowisata: Dari teori ke aplikasi. Yogyakarta: Andi Offset, 2006.

[12] A. M. Camilleri. Travel Marketing, Tourism Economics and the Airline Product. Switzerland: Springer, 2018.

[13] Buttler. The Concept of a Tourist Area Cycle Of Eolution: Implications For Management Of Resource, The Canadian Geographer, pp 5-12, 1980.

[14] P. Chandra and J. Kumar. Strategies for developing sustainable tourism business in the Indian Himalayan Region: Insights from Uttarakhand, the Northern Himalayan State of India , Journal of Destination Marketing \& Management, vol 19, pp. 1-9, 2021.

[15] R. J. David and S. Han. A systematic assessment of the empirical support for transaction cost economics, Strategic Management Journal, vol 25, No. 1, pp. 39-58, 2004.

[16] Grundey, Survutyre, Mingle, and J. Skimantaite. Prospects for sustainable tourism in Lithuania: a National Survey, Transformation in Business and Economics, vol 7, no. 1, pp 21-51, 2008.

[17] P. Kernel. Creating and Implementing a model for sustainable development in tourism enterprises, Journal of Cleaner Production vol 13, pp. 151-164, 2005. 